\title{
Phosphodiesterase inhibitors: new opportunities for the treatment of asthma
}

\author{
Theodore J Torphy, Bradley J Undem
}

Theophylline has been a mainstay in the treatment of asthma for over 50 years. Its therapeutic value stems from a combination of antiinflammatory and bronchodilator activities in addition to its ability to increase diaphragmatic contractility. ${ }^{1-4}$ Although the pharmacological effects of theophylline have been studied extensively both in the laboratory and in the clinic, the molecular mechanisms responsible for its activity in asthma remain ill defined. In fact, several cellular activities probably contribute to its action, including cyclic nucleotide phosphodiesterase inhibition, ${ }^{15}$ adenosine receptor antagonism, ${ }^{6}$ stimulation of catecholamine release, ${ }^{7}$ and a poorly understood ability to increase the number and activity of suppressor $\mathrm{T}$ lymphocytes. $^{8}$

Of theophylline's many activities, phosphodiesterase inhibition may be the most important. Hypothetically, at least two therapeutically beneficial effects could result from inhibition of phosphodiesterase activity and the consequent rise in intracellular adenosine $3^{\prime}, 5^{\prime}$-monophosphate (cAMP) or guan- osine 3',5'-monophosphate (cGMP) concentrations in key cells concerned in the pathophysiology of asthma (figure). Firstly, both cAMP and cGMP mediate airway smooth muscle relaxation, ${ }^{910}$ so a rise in either of these second messengers in airway smooth muscle should result in bronchodilatation. Secondly, the ability of PDE inhibitors to increase the cAMP content of inflammatory cells leads to an inhibition of cell activation. ${ }^{511} 12$ In principle, then, PDE inhibitors should possess antiinflammatory activity.

Although it is useful in the treatment of asthma, the value of theophylline is limited by a narrow therapeutic index and a wide range of gastrointestinal, central nervous system, and cardiovascular side effects. ${ }^{1-4}$ These side effects are generally ascribed to its lack of selectivity. Of particular importance in this respect is theophylline's ability to antagonise adenosine receptors and inhibit phosphodiesterase activity in inappropriate tissues (for example, gastrointestinal, central nervous system, cardiovascular). ${ }^{213}$ The development of drugs that couple the efficacy of theophylline
Department of Pharmacology, Smith Kline Beecham Pharmaceuticals, King of Prussia, Pennsylvania 19406 T J Torphy

Division of Clinical Immunology, Johns Hopkins University School of Medicine, Baltimore, Maryland 21224, USA 21224, USA

\section{Cyclic AMP}

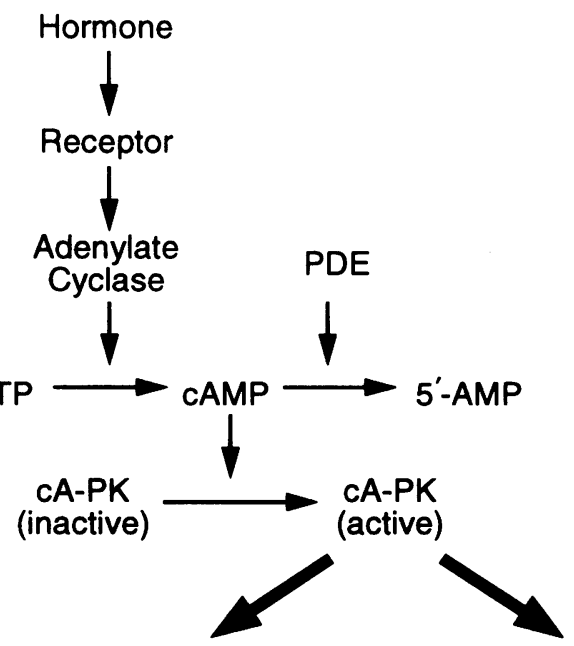

\section{Cyclic GMP}

Hormone

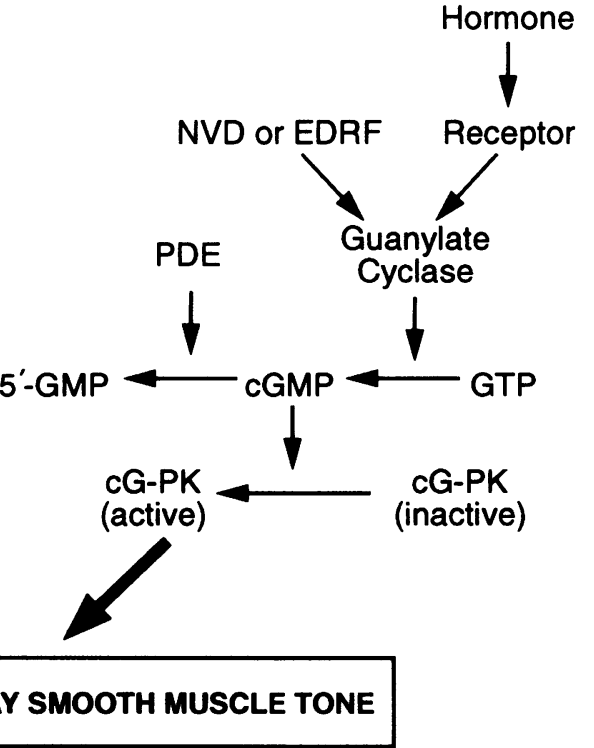

AIRWAY SMOOTH MUSCLE TONE

INFLAMMATORY CELL ACTIVITY

Role of cyclic nucleotides in the function of inflammatory cells and airway smooth muscle. See text for details. PDEphosphodiesterase; $c A-P K-c A M P$ dependent protein kinase; $c G-P K-c G M P$ dependent protein kinase; NVDnitrovasodilators; EDRF-endothelium derived relaxant factor. 
with an improved side effect profile and an increased therapeutic index would be an important advance in the treatment of asthma. Many pharmaceutical companies have attempted to improve the therapeutic profile of theophylline by synthesising and evaluating new xanthine analogues without specifically focusing on the phosphodiesterase inhibitory activity. So far these efforts have not been successful.

An alternative approach toward developing an "improved theophylline" has emerged recently. This approach is based on the premise that multiple, distinct forms of phosphodiesterases exist and that different phosphodiesterases are responsible for cyclic nucleotide hydrolysis in different tissues. Attempts are being made to increase tissue selectivity by synthesising inhibitors that are targeted against the major phosphodiesterase isozyme or isozymes responsible for regulating cAMP and cGMP hydrolysis in airway smooth muscle and inflammatory cells. Although some of these inhibitors have retained the xanthine nucleus, others have a completely different chemical structure. It is hoped that the phosphodiesterase inhibitors that emerge will retain at least some of the anti-inflammatory or bronchodilator activity (or both) of theophylline but that they will be less likely to produce gastrointestinal, central nervous system, and cardiovascular side effects by virtue of their poor activity against adenosine receptors and the phosphodiesterases present in gut, brain, and heart. The purpose of this review is to explain the theoretical foundation for the new generation of phosphodiesterase inhibitors in the treatment of asthma.

\section{Phosphodiesterase isozymes}

Hydrolysis of the 3'-phosphoester bond on cAMP or cGMP converts these second messengers to their inactive $5^{\prime}$-nucleotide metabolites (figure). This reaction is catalysed by a heterogeneous group of isozymes collectively known as phosphodiesterases. The general characteristics of phosphodiesterase isozymes are shown in table 1 . It is important to note that the kinetic values shown are approximations. Actual values may vary substantially, depending on the tissues, species, isolation procedure, and enzyme purity. The enzymes differ nevertheless in their kinetic and physical characteristics, substrate (cAMP or cGMP) selectivities, sensitivity to endogenous activators and inhibitors, susceptibility and response to phosphorylation by protein kinases, tissue distribution, and subcellular localisation..$^{14}$ Subclasses of isozymes may exist for each of the five families of phosphodiesterases shown in table $1 .^{14}$ Recent evidence suggests that the five families of phosphodiesterase isozymes are coded for by distinct but perhaps related genes. ${ }^{15-20}$

Phosphodiesterase (PDE)I, or the $\mathrm{Ca}^{2+} / \mathrm{cal}-$ modulin stimulated phosphodiesterase, as its name implies, is stimulated by $\mathrm{Ca}^{2+} / \mathrm{cal}-$ modulin. At least two general forms of the enzyme have been identified; the first (PDE $\mathrm{I}_{x}$ )
Table 1 Characteristics of phosphodiesterase isozymes

\begin{tabular}{llcc}
\hline & & \multicolumn{2}{c}{$K_{m}(\mu m o l l l) \dagger$} \\
\cline { 3 - 4 } Family* & Isozyme & $c A M P$ & $c G M P$ \\
\hline I $^{+}+$ & $\mathrm{Ca}^{2+} / \mathrm{CaM}$ stimulated & 30 & 3 \\
I $_{\beta+}^{+}$ & $\mathrm{Ca}^{2} /$ CaM stimulated & 1 & 2 \\
II & CGMP stimulated & 50 & 50 \\
III & cGMP inhibited & $0 \cdot 2$ & $0 \cdot 3$ \\
IV & cAMP specific & 2 & 100 \\
V & cGMP specific & 150 & 1 \\
\hline
\end{tabular}

*Nomenclature from ref 15

†Numbers represent approximate values (see ref 14); kinetic characteristics vary substantially, depending on species, tissue, isolation procedure, and enzyme purity.

$\ddagger$ The subsets of PDE I are arbitrarily designated $x$ and $\beta$.

has a much greater affinity for cGMP $\left(K_{m}=3\right.$ $\mu \mathrm{mol} / \mathrm{l})$ than for cAMP $\left(\mathrm{K}_{\mathrm{m}}=30 \mu \mathrm{mol} / \mathrm{l}\right)$, whereas the second (PDE $\mathrm{I}_{\beta}$ ) has an equal affinity $\left(K_{m}=1-2 \mu \mathrm{mol} / 1\right)$ for the two cyclic nucleotides. PDE II (cGMP stimulated phosphodiesterase) has a high $\mathrm{K}_{\mathrm{m}}$ for both cAMP and CGMP, and displays positive cooperativity with respect to substrate. The activity of this enzyme against cAMP is stimulated manyfold by "physiological" concentrations $(0 \cdot 1-1 \cdot 0 \mu \mathrm{mol} / \mathrm{l})$ of $\mathrm{cGMP}$. The isozyme with the lowest $\mathrm{K}_{\mathrm{m}}$ for cAMP and cGMP (about $0.3 \mu \mathrm{mol} / 1$ for both cyclic nucleotides) is PDE III. In contrast to PDE II, the ability of PDE III to hydrolyse cAMP is inhibited by low concentrations $(0 \cdot 1-1 \cdot 0 \mu \mathrm{mol} / \mathrm{l})$ of $\mathrm{cGMP}$. PDE IV is termed the cAMP specific phosphodiesterase because its affinity for cAMP $\left(\mathrm{K}_{\mathrm{m}}=2 \mu \mathrm{mol} / \mathrm{l}\right)$ is much greater than its affinity for cGMP $\left(\mathrm{K}_{\mathrm{m}}=100 \mu \mathrm{mol} / \mathrm{l}\right)$. The final isozyme, PDE $V$, is called the cGMP specific phosphodiesterase. This enzyme hydrolyses cAMP with a $\mathrm{K}_{\mathrm{m}}$ of more than 100 $\mu \mathrm{mol} / 1$ and cGMP with a $\mathrm{K}_{\mathrm{m}}$ of $1 \mu \mathrm{mol} / 1$.

An important point is that, whereas certain isozymes possess a degree of selectivity for cAMP or cGMP, all phosphodiesterases are capable of hydrolysing both cyclic nucleotides. Certain isozymes may also, for various reasons, be inactive in intact tissues. Thus, in the absence of additional information, it is impossible to predict which isozyme or isozymes are responsible for cyclic nucleotide hydrolysis in a tissue containing multiple phosphodiesterases simply by determining which isozymes are present in tissue homogenates.

From the standpoint of drug discovery the synthesis of compounds that possess a substantial degree of selectivity for one isozyme by comparison with others has been critical. ${ }^{21}$ These compounds are valuable pharmacological probes with which to assess the importance of various phosphodiesterase isozymes in regulating cyclic nucleotide content in intact tissues. More importantly, isozyme selective phosphodiesterase inhibitors may have therapeutic advantages over non-selective compounds (see below) and several isozyme selective phosphodiesterase inhibitors are, or were, being assessed in clinical studies for various disorders. Some examples are shown in table 2 . 
Table 2 Examples of isozyme selective phosphodiesterase (PDE) inhibitors

\begin{tabular}{|c|c|c|c|c|c|}
\hline Class & Drug & $\begin{array}{l}I C_{s 0} \\
(\mu \mathrm{mol} / \mathrm{l})^{\star}\end{array}$ & Source & Indication or action & Development stage ${ }^{\dagger}$ \\
\hline $\begin{array}{l}\text { 1. Calmodulin stimulated } \\
\text { (PDE I) }\end{array}$ & Vinpocetine & 15 & Wyeth-Ayerst & Nootropic + & Phase III \\
\hline 2. cGMP inhibited (PDE III) & $\begin{array}{l}\text { Anagrelide (BL 4162A) } \\
\text { Cilostamide (OPC 3689) } \\
\text { Enoximone (MDL 17043) } \\
\text { Imazodan (CI 914) } \\
\text { Milrinone (WIN 47203) } \\
\text { Siguazodan (SK\&F 94836) }\end{array}$ & $\begin{array}{l}0.05 \\
0.005 \\
1 \\
6 \\
0 \cdot 3 \\
1\end{array}$ & $\begin{array}{l}\text { Bristol-Myers Squibb } \\
\text { Otsuka } \\
\text { Marion Merrell Dow } \\
\text { Warner-Lambert } \\
\text { Sterling Winthrop } \\
\text { SmithKline Beecham }\end{array}$ & $\begin{array}{l}\text { Antithrombotic } \\
\text { Vasodilator } \\
\text { Inotropic } \\
\text { Inotropic } \\
\text { Inotropic } \\
\text { Inotropic }\end{array}$ & $\begin{array}{l}\text { Phase II } \\
\text { Discontinued } \\
\text { Phase III } \\
\text { Discontinued } \\
\text { Discontinued } § \\
\text { Discontinued }\end{array}$ \\
\hline 3. cAMP specific (PDE IV) & $\begin{array}{l}\text { Denbufylline (BRL 30892) } \\
\text { Ro 20-1724 } \\
\text { Rolipram (ZK 62711) } \\
\text { Tibenelast (LY 186655) } \\
\text { TVX 2706 }\end{array}$ & $\begin{array}{r}1 \\
5 \\
1 \\
20 \\
3\end{array}$ & $\begin{array}{l}\text { SmithKline Beecham } \\
\text { Hoffmann-LaRoche } \\
\text { Schering AG } \\
\text { Lilly } \\
\text { Troponwerke GmbH }\end{array}$ & $\begin{array}{l}\text { Multi-infarct dementia } \\
\text { Research } \\
\text { Antidepressant } \\
\text { Antiasthma } \\
\text { Anti-inflammatory }\end{array}$ & $\begin{array}{l}\text { Phase III } \\
\text { Discontinued } \\
\text { Discontinued } \\
\text { Phase III } \\
\text { Discontinued }\end{array}$ \\
\hline 4. Mixed PDE III/IV & $\begin{array}{l}\text { Benzafentrine (AH 21-132) } \\
\text { Zardaverine (B 842-90) }\end{array}$ & $\begin{array}{l}1-3 \\
1-3\end{array}$ & $\begin{array}{l}\text { Sandoz } \\
\text { Byk-Gülden }\end{array}$ & $\begin{array}{l}\text { Antiasthma } \\
\text { Antiasthma }\end{array}$ & $\begin{array}{l}\text { Discontinued } \\
\text { Phase II }\end{array}$ \\
\hline 5. cGMP specific (PDE V) & $\begin{array}{l}\text { Dipyridamole } \\
\text { MY-5445 } \\
\text { SK\&F } 96231 \\
\text { Zaprinast (M\&B 22,948) }\end{array}$ & $\begin{array}{l}1 \\
0 \cdot 5 \\
1 \\
1\end{array}$ & $\begin{array}{l}\text { Commercial } \\
\text { Mitsubishi Kasei } \\
\text { SmithKline Beecham } \\
\text { Rhone-Poulenc Rorer }\end{array}$ & $\begin{array}{l}\text { Vasodilator } \\
\text { Antithrombotic } \\
\text { Bronchodilator } \\
\text { Antiallergic }\end{array}$ & $\begin{array}{l}\text { Marketed } \\
\text { Preclinical } \\
\text { Preclinical } \\
\text { Discontinued }\end{array}$ \\
\hline
\end{tabular}

«Value represents $\mathrm{IC}_{50}$ against corresponding PDE isozyme. Each compound possesses a selectivity for the isozyme noted, although the degree of selectivity of the different compounds ranges from fivefold to several orders of magnitude.

tReflects development stage in the United States only.

†Nootropics represent a class of drugs that improve cognitive functions, such as learning, memory, reasoning, and understanding.

\$Development of oral form discontinued; an intravenous formulation was approved in the United States but has not yet been marketed.

$\mathrm{IC}_{50}$ - concentration causing a $50 \%$ inhibition of PDE activity.

Therapeutic hypothesis

Two important hypothetical considerations underpin the proposed use of isozyme selective phosphodiesterase inhibitors to treat asthma. The first is that the tissue distribution of phosphodiesterase isozymes is heterogeneous, ${ }^{1422-25}$ so that the isozymes responsible for the regulation of cyclic nucleotide content differs from tissue to tissue. Secondly, it should be possible to develop organ selective phosphodiesterase inhibitors by targeting the compounds at the predominant isozyme or isozymes in the tissue of interest, ${ }^{212627}$ and this has been achieved with the PDE III selective inhibitors. ${ }^{28-30}$ These compounds are directed against the major cAMP hydrolysing phosphodiesterase present in the myocardium and vasculature and thus are intended as inotropes possessing a modest degree of vasodilator activity. Although a positive effect of PDE III inhibitors on long term survival in patients with congestive heart failure has yet to be shown, these compounds have a pronounced beneficial effect on haemodynamics. ${ }^{29}{ }^{30}$ In contrast to previous agents that lacked isozyme selectivity (such as theophylline), the PDE III inhibitors produced few, if any, side effects that could be ascribed to phosphodiesterase inhibition in non-cardiovascular tissues. ${ }^{28}$ This supports the proposal that the side effect profile of phosphodiesterase inhibitors can be improved by synthesising compounds that possess a high degree of selectivity for the appropriate isozyme. An improved therapeutic index may permit higher doses of isozyme selective inhibitors to be administered-that is, doses that produce a substantially greater inhibition of the relevant isozyme than do non-selective inhibitors. The clinical efficacy of isozyme selective phosphodiesterase inhibitors may then be greater than that of their non-selective counterparts.

The second factor to consider with regard to the efficacy of PDE inhibitors is that their ability to increase cyclic nucleotide content is related to the basal activity of adenylate or guanylate cyclase in target tissues, a consequence of the synergism between phosphodiesterase inhibitors and activators of adenylate cyclase (for example, beta adrenoceptor agonists) or guanylate cyclase (for example, nitrovasodilators). The effect of theophylline in asthma has been attributed to potentiation of the effects of endogenous activators of adenylate cyclase. ${ }^{5132}$ The importance of phosphodiesterase inhibition in the therapeutic activity of theophylline has, however, been questioned, ${ }^{2133}$ primarily because the plasma concentrations of unbound theophylline that elicit bronchodilatation in vivo produce only a modest $(10-20 \%)$ inhibition of phosphodiesterase activity in human lung extracts. ${ }^{334}$ This degree of inhibition in the presence of endogenous adenylate or guanylate cyclase activators may, however, be sufficient to produce a substantial increase in cyclic nucleotide content in airway smooth muscle and inflammatory cells. ${ }^{52}$ This proposal is supported by the fact that therapeutic concentrations of theophylline act synergistically with exogenously administered activators of adenylate cyclase to inhibit human polymorphonuclear leucocyte activation ex vivo. ${ }^{3135}$

In contrast to the results with human polymorphonuclear leucocytes, most studies in asthmatic subjects have detected only an additive bronchodilator effect when a beta adrenoceptor agonist and theophylline are given together, ${ }^{36-38}$ though a synergistic interaction has been observed on occasion. ${ }^{39}$ One possible explanation for the failure to detect a synergistic interaction in vivo is that theophylline produces bronchodilatation by several cellular mechanisms in addition to phosphodiesterase inhibition.

Several endogenously released agents are 
capable of stimulating adenylate cyclase activity in inflammatory cells and airway smooth muscle, and could thus act to potentiate the responses to phosphodiesterase inhibitors. These include (1) circulating catecholamines irom the adrenal medulla ${ }^{40} ;(2)$ prostaglandin $\mathrm{E}_{2}\left(\mathrm{PGE}_{2}\right)$ from monocytes, alveolar macrophages, ${ }^{41}$ and airway epithelial cells ${ }^{42}$; (3) prostacyclin $\left(\mathrm{PGI}_{2}\right)$ from vascular endothelial cells ${ }^{43}$; and (4) neurotransmitters from pulmonary adrenergic neurones and inhibitory nonadrenergic non-cholinergic (i-NANC) neurones (for example, vasoactive intestinal polypeptide). ${ }^{44} 45$ The role of these endogenous adenylate cyclase activators in regulating the responsiveness of target cells to phosphodiesterase inhibitors is speculative. Local concentrations of autacoids such as $\mathrm{PGE}_{2}$ and $\mathrm{PGI}_{2}$ are increased in areas of inflammation and after antigenic stimulation, ${ }^{46}$ so the functional response to phosphodiesterase inhibitors may be greater in the inflamed lungs of patients with asthma than in non-inflamed tissues. Cyclooxygenase inhibitors and beta adrenoceptor antagonists could reduce the therapeutic activity of phosphodiesterase inhibitors, though to our knowledge neither of these possibilities has been tested.

\section{Airway smooth muscle}

ROLE OF CYCLIC NUCLEOTIDES

The mechanisms by which cyclic nucleotides mediate smooth muscle relaxation has been the subject of several recent reviews. ${ }^{91047-49}$ An in depth discussion of this topic is beyond the scope of this review, but a brief overview of the proposed roles of CAMP and CGMP in regulating airway smooth muscle tone is given; further details can be obtained elsewhere. ${ }^{9} 104748$

As depicted schematically in the figure, intracellular cyclic nucleotide content is increased by increasing the rate at which cyclic nucleotides are formed or by decreasing the rate at which they are degraded. Activators of adenylate cyclase (such as beta adrenoceptor agonists and prostaglandins $\mathrm{E}_{2}$ and $\mathrm{I}_{2}$ ) bind to cell surface receptors and, through a guanine nucleotide binding protein, increase the rate at which $\mathrm{Mg}^{2+}-\mathrm{ATP}$ is converted to cAMP. In contrast to the regulation of adenylate cyclase, agents such as the nitrovasodilators (for example, sodium nitroprusside, nitroglycerin) and endothelium derived relaxant factor (probably nitric oxide) activate soluble guanylate cyclase activity directly without interacting with a cell

Table 3 Summary of phosphodiesterase (PDE) isozymes in airway smooth muscle

\begin{tabular}{|c|c|c|c|}
\hline Species & Tissue & Isozymes & Reference(s) \\
\hline $\begin{array}{l}\text { Canine } \\
\text { Bovine } \\
\text { Guinea pig } \\
\text { Human } \\
\text { Human }\end{array}$ & $\begin{array}{l}\text { Trachealis } \\
\text { Trachealis } \\
\text { Trachealis } \\
\text { Bronchus } \\
\text { Trachealis }\end{array}$ & $\begin{array}{l}\text { I }_{\beta}, \text { II }, I I I, I V, \text { V } \\
\text { I, II }, I^{\star}+ \\
\text { III, IV }+ \\
\text { I, III }, \text { IV }, V^{\star} \S \\
I_{x}, I_{\beta}, I I, I I I, I V, V^{\star \star}\end{array}$ & $\begin{array}{l}51,52 \\
53,54 \\
51 \\
55 \\
56\end{array}$ \\
\hline
\end{tabular}

* Subclassification of PDE I (that is, $x$ or $\beta$ ) has not yet been determined.

+ Fraction designated PDE I may also contain PDE V.

+At least two additional fractions of phosphodiesterase activity eluting from anion-exchange columns were not characterised.

PDE II may be present but not detected.

* Results based on preliminary characterisation. surface receptor. A distinct particulate guanylate cyclase is stimulated by the atriopeptins through a receptor mediated mechanism that is not dependent on a guanine nucleotide binding protein.

The intracellular target enzymes for cAMP and cGMP are cAMP dependent and cGMP dependent protein kinases. As cellular concentrations of cAMP or cGMP rise the appropriate cyclic nucleotide binds to and activates its corresponding protein kinase. The activated protein kinases then mediate the physiological responses to cyclic nucleotides by phosphorylating and thus changing the activity of key substrates (such as enzymes and ion transport systems) concerned in the regulation of smooth muscle tone. Several relevant substrates are likely to be phosphorylated by cAMP dependent and cGMP dependent protein kinases in airway smooth muscle. ${ }^{910}$ In brief, the increases in cAMP or cGMP content can produce airway smooth muscle relaxation by two general mechanisms. Firstly and perhaps most importantly, an increase in cyclic nucleotide concentrations leads to a decrease in the cytosolic free $\mathrm{Ca}^{2+}$ concentration by reducing the mobilisation of $\mathrm{Ca}^{2+}$ from intracellular stores, inhibiting the influx of extracellular $\mathrm{Ca}^{2+}$, stimulating $\mathrm{Ca}^{2+}$ efflux or increasing $\mathrm{Ca}^{2+}$ sequestration into intracellular storage sites. Secondly, activation of the cAMP or cGMP protein phosphorylation cascades may inhibit the activity of contractile proteins directly. Several of these biochemical pathways are likely to be activated simultaneously and act in a coordinated fashion to reduce airway smooth muscle tone.

Bronchodilators that act through second messenger pathways-for example, beta adrenoceptor agonists and phosphodiesterase inhibitors-should relax airway smooth muscle regardless of the mediator or mediators responsible for inducing bronchoconstriction. This should be an advantage in a disease such as asthma in which several mediators may act in concert to elicit bronchoconstriction.

\section{PHOSPHODIESTERASE ISOZYMES IN AIRWAY SMOOTH MUSCLE}

Over the last 15 years, and especially the last five, several reports have described phosphodiesterase isozyme profiles in airway smooth muscle from various species (table 3). ${ }^{50-56} \mathrm{~A}$ few caveats must be considered in any discussion of the results of these studies. Firstly, kinetic analyses of enzyme activity have generally been carried out with crude or at best partially purified preparations. To our knowledge, there have been no reports of studies in which every phosphodiesterase isozyme present in airway smooth muscle has been purified to homogeneity. Secondly, airway smooth muscle preparations are not homogeneous in terms of cellular content and at least some of the phosphodiesterase activity present in homogenates of airway smooth muscle will come from submucosal glands, capillary endothelial cells, fibroblasts, neurones, mast cells, etc. Thirdly, as discussed later, the presence of a phosphodiesterase isozyme in a tissue homo- 
genate does not necessarily indicate a physiological role for that isozyme. Fourthly, only recently have highly selective and potent inhibitors of phosphodiesterase isozymes been available as pharmacological probes; many published studies on the functional responses of airway smooth muscle to phosphodiesterase inhibitors have used compounds that are not isozyme selective. Finally, virtually all studies describing phosphodiesterase activity in airway smooth muscle have concentrated on tracheal smooth muscle. We do not yet know whether isozyme profiles differ between central and peripheral airways.

Phosphodiesterase isozyme profiles have been studied more extensively in the canine trachealis than in any other type of airway smooth muscle. Polson and colleagues used anion exchange chromatography to separate phosphodiesterases from the soluble fraction of canine trachealis homogenates almost a decade ago. ${ }^{50}$ Five apparently distinct peaks of phosphodiesterase activity eluted from the column, though only one of these was characterised kinetically. The phosphodiesterase in this peak was not stimulated by $\mathrm{Ca}^{2+} /$ calmodulin and hydrolysed cAMP with a $\mathrm{K}_{\mathrm{m}}$ of $0.6 \mu \mathrm{mol} / 1$ and cGMP with a $\mathrm{K}_{\mathrm{m}}$ of $3 \mu \mathrm{mol} / 1$. On the basis of the characteristics outlined in table 1 , these data suggest that at least one of the isozymes in canine trachealis is PDE III. More recently, at least two groups have used conventional chromatographic techniques to separate canine tracheal phosphodiesterases and have then identified the isozymes present by means of kinetic analyses, isozyme specific modulators of enzyme activity (for example, cGMP, $\mathrm{Ca}^{2+}$ / calmodulin), and isozyme selective phosphodiesterase inhibitors. ${ }^{51} 52$ These studies have shown five distinct phosphodiesterase isozymes, including phosphodiesterases $\mathrm{I}_{\beta}$, II, III, IV, and V. There appears to be a differential subcellular distribution of these isozymes in that PDE II is absent from high speed membrane fractions, whereas PDE III is enriched in membrane fractions. ${ }^{52}$ Although five isozymes are present in canine trachealis, some make a minimal contribution to total cyclic nucleotide phosphodiesterase activity in tissue homogenates. ${ }^{9}$

Bovine and guinea pig tracheal phosphodiesterase isozymes have also been isolated and characterised. Cytosolic fractions of bovine trachealis homogenates contain phosphodiesterases I, II, and IV. ${ }^{5354}$ In view of the substantial inhibitory potency of zaprinast against the enzyme described as phosphodiesterase $I^{534}$ perhaps, as in canine trachealis, ${ }^{52}$ the enzyme preparation designated PDE I in these studies also contained PDE V. PDE III was conspicuously absent from the soluble fraction of bovine trachealis homogenates; whether it is present in the membrane fraction of this tissue is not yet known. Isolation and partial characterisation of phosphodiesterases from guinea pig tracheal smooth muscle indicate the presence of both PDE III and PDE IV. ${ }^{51}$ At least two other peaks of phosphodiesterase activity were eluted from anion exchange columns, but the enzyme activity in these fractions were not characterised. ${ }^{51}$
Finally, a limited amount of work has been directed toward defining the phosphodiesterase isozyme profile of human airway smooth muscle. In an early study by Bergstrand and Linquist, ${ }^{55}$ at least four distinct peaks of PDE activity were isolated from human bronchial tissue by anion exchange chromatography. The kinetic characteristics of the different activities suggest the presence of PDEs I, III, IV, and V. The fact that this study was carried out with bronchial tissue, a preparation containing a highly heterogenous cell population, raises the question of whether one or more of the PDEs identified were present in contaminating cells rather than in the smooth muscle. The results are supported, however, by a recent preliminary report on human tracheal smooth muscle, ${ }^{56}$ which appears to contain all the phosphodiesterases present in bronchial tissue as well as PDE II, ${ }^{56}$ an enzyme that would probably not have been detected by the techniques used in the earlier study.

\section{ACTION OF ISOZYME SELECTIVE}

PHOSPHODIESTERASE INHIBITORS ON AIRWAY SMOOTH MUSCLE

Identification of a PDE isozyme in a tissue does not provide information on the relative importance of the isozymes in regulating cyclic nucleotide content in vivo. One approach to defining the physiological role of phosphodiesterase isozymes, and hence appropriate molecular targets for new therapeutic agents, is to examine the biochemical and functional effects of isozyme selective inhibitors in intact tissues. Polson and colleagues determined the potency of various xanthines as inhibitors of two distinct phosphodiesterase activities isolated from canine trachealis: a low $\mathrm{K}_{\mathrm{m}}$ cAMP phosphodiesterase, probably PDE III, and a second phosphodiesterase activity, perhaps representing a mixture of isozymes, which preferred cGMP as a substrate. ${ }^{50} 57$ When potencies of the various xanthines as inhibitors of the two phosphodiesterase activities were then related to their potencies as relaxants of methacholine contracted trachealis strips a remarkably good correlation was observed, ${ }^{50}$ suggesting that the xanthines examined were relaxing canine trachealis by inhibiting the activity of a specific cAMP or cGMP phosphodiesterase. The results of these studies, the first to describe a correlation between inhibition of distinct phosphodiesterase activities and relaxation of airway smooth muscle, cannot be interpreted unequivocally. One problem was the use of alkylxanthines that inhibited cAMP and cGMP phosphodiesterase activities nonselectively. Consequently, the potency order of the compounds for inhibition of the cAMP phosphodiesterase activity ${ }^{50}$ was identical to that for inhibition of the cGMP phosphodiesterase activity. ${ }^{57}$ This and the lack of information on the effect of these compounds on cyclic nucleotide content in intact trachealis strips makes it difficult to determine whether the relaxant response of the trachealis to the phosphodiesterase inhibitors was due to inhibition of either the CAMP or the CGMP phosphodiesterase activity, or both. 
More recently, the physiological role of various phosphodiesterase isozymes in canine trachealis has been examined by correlating the functional response (relaxation) of the tissue to isozyme selective phosphodiesterase inhibitors with the biochemical response (cyclic nucleotide content) to these compounds. ${ }^{58} 59$ Siguazodan (SK\&F 94836), a highly selective PDE III inhibitor, ${ }^{5260}$ produced a concentration dependent relaxation of methacholine or histamine contracted canine trachealis strips that was associated with an increase in cAMP content and an activation of cAMP dependent protein kinase. ${ }^{58}$ On the other hand, siguazodan had no effect on the functional or biochemical (that is, cGMP accumulation) responses to sodium nitroprusside, ${ }^{58}$ a guanylate cyclase activator that is thought to relax airway smooth muscle via a cGMP mediated mechanism. ${ }^{10}$ These results provide strong evidence to support a major role for PDE III in regulating cAMP content but not cGMP content in intact canine trachealis.

A similar approach was taken in another study aimed at defining the roles of PDE III, IV, and $\mathrm{V}$ in canine trachealis. ${ }^{59}$ These experiments assessed the ability of various isozyme selective PDE inhibitors to potentiate the functional and biochemical responses to isoprenaline or sodium nitroprusside. The phosphodiesterase inhibitors used were SK\&F 94120, Ro 20-1724, and zaprinast, all of which had been shown to selectively inhibit canine tracheal PDE III, PDE IV, and PDE V respectively. ${ }^{52}$ Isoprenaline induced relaxation and cAMP accumulation were potentiated by both SK\&F 94120 and Ro 20-1724, but these agents had no effect on the response to sodium nitroprusside. In contrast, zaprinast potentiated sodium nitroprusside induced relaxation and cGMP accumulation, but did not potentiate the responses to isoprenaline. These results suggest that PDE III and PDE IV hydrolyse cAMP in intact canine trachealis, whereas PDE V hydrolyses cGMP. ${ }^{59}$

Several studies have shown the potent relaxant activity of PDE III inhibitors on the guinea pig isolated trachea, providing further support for a role for this isozyme in regulating airway smooth muscle cAMP content. ${ }^{61-63}$ Harris and colleagues found an excellent correlation between the ability of a series of compounds to relax guinea pig trachea and their ability to inhibit PDE III isolated from guinea pig trachealis. ${ }^{03}$ An analogous series of experiments conducted with a different set of compounds showed no relation between relaxation and PDE IV inhibition but, inexplicably, relaxation did correlate with the ability of these compounds to compete with a high affinity rolipram binding site. ${ }^{63}$ The nature and function of this high affinity rolipram binding site have yet to be defined, ${ }^{64}$ but it may represent a discrete subtype of PDE IV. There was pronounced synergism between the relaxant activity of PDE III inhibitors and compounds that bind to the high affinity rolipram binding site. For example, the $\mathrm{EC}_{50}$ for rolipram was reduced nearly 25 fold in the presence of a fixed concentration of CI-930, a PDE III inhibitor. ${ }^{63}$
Finally, a role for PDE V in regulating cGMP content in guinea pig airway smooth muscle is suggested by the observation that SK\&F 96231, a selective PDE V inhibitor, relaxes guinea pig isolated trachea in a concentration dependent manner. ${ }^{65}$

The biochemical response of guinea pig trachealis to isozyme selective phosphodiesterase inhibitors has not been studied in great detail. The PDE III inhibitor SK\&F 94120 and the mixed PDE III/IV inhibitor benzafentrine (AH 21-132) increase cAMP content in muscle rich guinea pig tracheal preparations, though detectable increases in cAMP content are observed only with concentrations of these compounds that produce near maximal relaxation. ${ }^{6166}$ Much lower concentrations of benzafentrine substantially potentiated the ability of a threshold concentration of forskolin to elevate cAMP content in this preparation. Benzafentrine, ${ }^{66}$ but not SK\&F $94120,{ }^{61}$ also increases cGMP content in guinea pig trachealis. SK\&F 96231, a PDE V inhibitor, increased cGMP content in guinea pig lung parenchymal strips. ${ }^{65}$ Although the strips contain many cell types in addition to airway smooth muscle, this observation implies that inhibition of PDE V in intact tissues can lead to a rise in cGMP content.

The bronchorelaxant activity of isozyme selective phosphodiesterase inhibitors in the guinea pig is not limited to in vitro preparations. Various PDE III, PDE IV, mixed PDE III/IV, and PDE V inhibitors have substantial bronchodilator activity in anesthetised guinea pigs $^{636567-71}$ and, as in experiments in vitro, the bronchodilatation appears to occur regardless of the spasmogen used to induce tone.

The effects of isozyme selective phosphodiesterase inhibitors in bovine airway smooth muscle have not been examined as extensively as in guinea pig or canine airway smooth muscle and there are no data correlating relaxant responses with changes in cyclic nucleotide content. Preliminary data suggesting that rolipram is a potent relaxant of bovine trachealis imply an important role for PDE IV in regulating cAMP content in this tissue ${ }^{54}{ }^{72} \mathrm{On}$ the other hand, the role of PDE III in bovine trachealis is somewhat ambiguous. Although the PDE III inhibitors SK\&F 94120 and milrinone relax this tissue, the potency and efficacy of both compounds are distinctly low. ${ }^{54} 72$ The poor relaxant activity of PDE III inhibitors, coupled with the failure to detect PDE III in the soluble fraction of bovine trachealis homogenates, ${ }^{535}$ raises doubt about the functional role of PDE III in this tissue. The functional role of PDE $\mathrm{V}$ in the bovine trachea appears to be minor as zaprinast has little or no relaxant activity in this tissue..$^{5467}$

Functional effects of isozyme selective phosphodiesterase inhibitors on human isolated airway smooth muscle have not yet been reported, though several groups are actively engaged in this area of research and results of these studies should be available soon.

One final caveat concerns the interpretation of the data discussed in this section: no phosphodiesterase inhibitors possess absolute 
isozyme specificity. When present in high concentrations all isozyme selective inhibitors will inhibit phosphodiesterases other than the ones against which they are targeted. Certain isozyme selective phosphodiesterase inhibitors may also regulate physiological processes by mechanisms that are unrelated to phosphodiesterase inhibition. For example, the ability of rolipram to inhibit agonist induced generation of inositol phosphates in bovine trachealis may be unrelated to phosphodiesterase inhibition and cAMP accumulation. ${ }^{73}$ Thus conclusions on the role of individual phosphodiesterase isozymes in intact tissues drawn from experiments with isozyme selective phosphodiesterase inhibitors are somewhat tenuous, particularly in the absence of corroborative biochemical data.

\section{Inflammatory cells}

ROLE OF CYCLIC NUCLEOTIDES

The vast number of published papers leaves little doubt that cAMP acts as an inhibitory messenger in inflammatory cells. ${ }^{511} 12$ In addition to inhibiting inflammatory mediator production and release, it is evident that an increase in cellular cAMP inhibits other functions of inflammatory cells, including chemotaxis, cytotoxicity and cell aggregation. Thus increases in cAMP content have a generalised suppressive influence on human inflammatory cells (figure).

More than 20 years ago Lichtenstein and coworkers suggested that an increase in cellular cAMP led to an inhibition of antigen induced histamine release from human basophils. ${ }^{74}$ This speculation was based on the observation that beta adrenoceptor agonists and theophylline were effective inhibitors of antigen induced histamine release from human mixed leucocyte preparations, and was consistent with the observations made by Schild some 30 years earlier that epinephrine is a potent inhibitor of anaphylactic histamine release from lung tissue. ${ }^{75}$ Various compounds that either stimulate adenylate cyclase or inhibit cyclic nucleotide phosphodiesterase (see

Table 4 Summary of phosphodiesterase (PDE) isozymes in human inflammatory cells

\begin{tabular}{|c|c|c|c|}
\hline Cell type & $\begin{array}{l}\text { Predominant } \\
P D E \\
\text { isozyme }(s)+\end{array}$ & $\begin{array}{l}\text { Effect of PDE } \\
\text { inhibitors }+\end{array}$ & Reference (s) \\
\hline Basophil & IV & $\downarrow$ Mediator release & 88 \\
\hline Mast cell & IV & Mediator release & 32 \\
\hline Neutrophil & IV & $\begin{array}{l}\text { Mediator release } \\
\text { Respiratory burst }\end{array}$ & 90,99 \\
\hline Eosinophil* & IV & Superoxide formation & 76 \\
\hline Monocyte & IV & $\begin{array}{l}\text { Mediator release } \\
\downarrow \text { Cytokine formation }\end{array}$ & $77,91,93,103,104$ \\
\hline Lymphocyte & III, IV & $\begin{array}{l}\downarrow \text { Cytotoxicity } \\
\downarrow \text { IgE formation } \\
\downarrow \text { Cytokine formation } \\
\downarrow \text { Blastogenesis }\end{array}$ & $91,92,98,100,101$ \\
\hline Platelet & III & $\begin{array}{l}\downarrow \text { Aggregation } \\
\downarrow \text { Mediator release }\end{array}$ & $58,89,94,105,106$ \\
\hline
\end{tabular}

* So far only studies with guinea pig eosinophils have been conducted.

tOnly the major CAMP metabolising enzyme or enzymes are listed.

†Represents the effect of either isozyme selective or non-selective phosphodiesterase inhibitors; $\ddagger$ Represents the effect of either isozyme selective or non-selective phosphodiesterase inhibitors;
although a few of the cited studies were conducted with non-selective compounds, the overall although a few of the cited studies were conducted with non-selective compounds, the overall
pharmacological effect observed is likely to have been due to inhibition of the major pharmacological effect observed is likely to
phosphodiesterase isozyme present in the cell. below) are now known to have inhibitory effects on many inflammatory cell types, including eosinophils, neutrophils, monocytes, platelets, basophils, and mast cells. . $^{1112} 126-79$

Although many pharmacological studies have shown that increasing cAMP content inhibits inflammatory cell activity, there is little information on the specific mechanisms mediating this inhibitory effect, though it appears to be due to multiple mechanisms. As with the studies on smooth muscle discussed above, evidence indicates that at least one of the mechanisms by which cAMP suppresses inflammatory cell activity includes an inhibitory effect on stimulus induced increase in cytosolic $\mathrm{Ca}^{2+} .^{780-85}$ Because an increase in cytosolic $\mathrm{Ca}^{2+}$ is a trigger for several cellular activities, including mediator production and release, inhibiting this event would be expected to cause a general inhibition of inflammatory cell function. There is also evidence, however, that cAMP can inhibit mediator release in the absence of gross changes in cytosolic $\mathrm{Ca}^{2+}$ concentrations. ${ }^{84}$ In mast cells a rise in cAMP is much more effective in inhibiting antigen induced eicosanoid biosynthesis than in inhibiting the rise in cytosolic $\mathrm{Ca}^{2+}$ or histamine release ${ }^{8486}$ In the case of eicosanoid biosynthesis, it has been suggested that activation of the cAMP cascade may cause direct inhibition of an enzyme or enzymes in the biosynthetic pathway (for example, phospholipase $\mathrm{A}_{2}$ ). ${ }^{84}$

Much less is known about the role of cGMP in the regulation of inflammatory cell function. An increase in cGMP may enhance antigen induced histamine release from human lung mast cells. ${ }^{87}$ These studies, however, were carried out on lung parenchymal fragments, so the biochemical data are difficult to interpret. Neither sodium nitroprusside nor dibutyryl cGMP inhibited immunological mediator release from human basophils ${ }^{88}$ or isolated human lung mast cells in our studies (unpublished observations). Although the precise role of cGMP in regulating inflammatory cell function is uncertain, its effect appears to be modest by comparison with the profound inhibitory effect of cAMP.

\section{PHOSPHODIESTERASE ISOZYMES IN} INFLAMMATORY CELLS

The profile of phosphodiesterase isozymes in inflammatory cells has been obtained only recently (table 4). Chromatographic analyses combined with kinetic and pharmacological characterisations show that PDE IV is the major phosphodiesterase isozyme responsible for catabolising cAMP in several human inflammatory cell types, including mast cells, basophils, monocytes, and neutrophils. In contrast, PDE III is the predominant isozyme in platelets and a combination of PDE III and PDE IV is present in mixed lymphocyte preparations.

The next section looks at the identity of the predominant cAMP phosphodiesterase activity in various inflammatory cells. In virtually all the cells studied so far, however, minor activity from one or more phosphodiesterases has been found in addition to the major activity. In the basophil and platelet, for exam- 
ple, the additional phosphodiesterase is selective for cGMP and is inhibited by zaprinast, ${ }^{88} 89$ suggesting that it is PDE V. On the basis of the substrate specificity this isozyme seems unlikely to have a physiological role in the catabolism of cAMP. Thus selectively inhibiting this isozyme is unlikely to lead to a rise in cellular cAMP.

\section{Basophil and mast cell}

In the human basophil most of the cAMP hydrolysis activity is accounted for by PDE IV $\left(\mathrm{K}_{\mathrm{m}}=1.6 \mu \mathrm{mol} / \mathrm{l}\right){ }^{88} \mathrm{~A}$ small portion (under $20 \%$ ) of the activity is attributed to PDE III $\left(\mathrm{K}_{\mathrm{m}}=0.3 \mu \mathrm{M}\right)$, on the basis of the observations that the low $\mathrm{K}_{\mathrm{m}}$ isozyme was inhibited by cGMP and the selective PDE III inhibitor SK\&F 95654. The phosphodiesterase isozyme profile in human mast cell populations is not known. Mouse mast cells derived from mouse bone marrow contain a single cAMP hydrolysing isozyme with kinetic and pharmacological characteristics of PDE IV. ${ }^{32}$

\section{Neutrophil}

The cAMP PDE activity in the human neutrophils is eluted from DEAE anion exchange columns in a single peak, has a $\mathrm{K}_{\mathrm{m}}$ of $0.7 \mu \mathrm{mol} / 1$, and is sensitive to inhibition by the selective PDE IV inhibitors rolipram and Ro 20-1724. ${ }^{90}$ These findings suggest that the phosphodiesterase isozyme responsible for hydrolysing cAMP in the human neutrophil is predominantly if not exclusively PDE IV.

\section{Lymphocyte}

Systematic evaluation of the PDE isozyme profile in the various subtypes of lymphocytes has not been performed to our knowledge. Thompson and coworkers reported that a mixed lymphocyte preparation (99\% lymphocytes) contains a single phosphodiesterase isozyme with a low $\mathrm{K}_{\mathrm{m}}(0.40 \mu \mathrm{mol} / 1)$ for cAMP hydrolysis and a much higher $\mathrm{K}_{\mathrm{m}}$ for cGMP hydrolysis. ${ }^{91}$ The elution profile and kinetic characteristics suggest that the isozyme is PDE III. Both PDE III and PDE IV may be present in $T$ lymphocytes because in preparations enriched in $T$ lymphocytes two high affinity cAMP selective phosphodiesterases exist, one of which is inhibited by Ro 20-1724 and another which is not. ${ }^{92}$ The different isozyme profile observed in these cells versus mixed lymphocytes raises the possibility that different subsets of lymphocyte may contain different phosphodiesterases. $^{92}$

\footnotetext{
Monocyte

Purified monocyte preparations isolated from peripheral blood contain a single cAMP selective phosphodiesterase with a $K_{m}$ of 1.3 $\mu \mathrm{mol} / 1^{91}$; this isozyme appears to be PDE IV. This is supported by a preliminary study in which the major cAMP phosphodiesterase in monocytes was partially purified and characterised $^{93}$ and shown to have the kinetic characteristics (cAMP $\mathrm{K}_{\mathrm{m}}=1.8 \mu \mathrm{mol} / \mathrm{l}$ ) and pharmacological properties (inhibited by rolipram and Ro 20-1724) consistent with its being PDE IV.
}

Platelet

The predominant phosphodiesterase isozyme in the human platelet is PDE III. ${ }^{60894}$ This isozyme has a $\mathrm{K}_{\mathrm{m}}$ for both cAMP and cGMP of about $0.4 \mu \mathrm{mol} / 1$, is selectively inhibited by several PDE III inhibitors, including cilostamide, milrinone, and siguazodan, and is inhibited by cGMP $\left(\mathrm{IC}_{50} \sim 0.1 \mu \mathrm{mol} / \mathrm{l}\right)$, a distinct characteristic of PDE III.

\section{ACTION OF ISOZYME SELECTIVE INHIBITORS ON} INFLAMMATORY CELL FUNCTION

In view of the individual profile of phosphodiesterase isozymes in inflammatory cells, and knowledge that a rise in CAMP has potent anti-inflammatory activity, it is reasonable to propose that isozyme selective inhibitors may be useful as anti-inflammatory agents in the treatment of asthma. Information on the functional consequence of selective inhibition of phosphodiesterase isozymes in human inflammatory cells is summarised below. Because much of the work is recent some conclusions are drawn from data that are unpublished or published only as abstracts. Appropriate caution in these areas is warranted. In general the PDE isozyme profile in the respective cell type appears to be a good predictor of the pharmacology of isozyme-selective inhibitors (table 4).

\section{Mast cell}

SK\&F 95654 and zaprinast, inhibitors of PDE III and PDE V respectively, have little or no effect on immunologically stimulated mediator release from human isolated lung mast cells. ${ }^{32}$ In contrast, rolipram and Ro 20-1724 inhibit antigen induced mediator release from these cells, and potentiate the inhibitory effect of adenylate cyclase activators. ${ }^{32}$ The effect of isozyme selective inhibitors on human lung mast cells is mimicked in the mouse bone marrow derived mast cell. In these cells PDE IV inhibition reduces antigen induced histamine release and leukotriene $\mathrm{C}_{4}$ production, whereas zaprinast and siguazodan are without effect. ${ }^{32}$ Interestingly, the rat peritoneal mast cell appears to respond differently to isozyme selective inhibitors from both the human lung mast cell and the mouse bone marrow derived mast cell. In this cell type submicromolar concentrations of zaprinast effectively inhibit immunologically induced histamine release, whereas rolipram has little effect. ${ }^{95}$ Whether this reflects a species difference or is a result of microenvironment dependent mast cell heterogeneity is unknown.

\section{Basophil}

Inhibiting PDE IV with rolipram or Ro 201724 effectively inhibits antigen-induced histamine and leukotriene $\mathrm{C}_{4}$ release from human basophils. ${ }^{89596}$ Rolipram also potentiates the inhibitory effect of forskolin on mediator release from these cells. ${ }^{95}$ Neither zaprinast nor SK\&F 95654 influences antigen induced mediator release from the human basophil, but SK\&F 95654 potentiates the inhibitory effect of rolipram. This potentiation is observed both for inhibition of mediator release and increase 
in cellular cAMP. ${ }^{95}$ Thus there appears to be a synergistic interaction between the inhibitors of PDE III and PDE IV in the basophil Combinations of PDE III and PDE IV inhibitors have also been reported to act synergistically in guinea pig trachealis, rat ventricle, and human lymphocyte. ${ }^{639798}$ Examination of the effects of various combinations of isozyme selective phosphodiesterase inhibitors on inflammatory cell function deserves further attention.

\section{Neutrophil}

The neutrophil respiratory burst is inhibited by the PDE IV inhibitors, rolipram, and Ro 20 1724. ${ }^{90}$ The effectiveness of these inhibitors is equal to that of the relatively non-selective phosphodiesterase inhibitors theophylline and enprofylline. The phosphodiesterase profile of these cells suggests that PDE IV is the only phosphodiesterase isozyme regulating cAMP content in neutrophils. Thus selective concentrations of zaprinast and various PDE III inhibitors are without effect on the respiratory burst in this cell type. Inhibition of phosphodiesterase and increase in cAMP have also been found to inhibit lysozyme release from neutrophils and the synthesis of platelet activating factor and $\mathrm{LTB}_{4}{ }^{79}{ }^{99}$

\section{Eosinophil}

No information is available on the effect of isozyme selective phosphodiesterase inhibitors on human eosinophil function. In a preliminary report Dent and coworkers reported that PDE IV selective inhibitors reduce superoxide formation in guinea pig eosinophils. ${ }^{76}$

\section{Lymphocyte}

The PDE IV inhibitor Ro 20-1724 inhibits the activity of human cytotoxic $T$ lymphocytes ${ }^{100}$ and interleukin-2 production by human $T$ lymphocytes. ${ }^{101}$ In addition, both Ro 20-1724 and CI-930, a PDE III inhibitor, cause a modest inhibition of blastogenesis in $\mathrm{T}$ lymphocytes. $^{98}$ These agents have a much more pronounced inhibitory effect on blastogenesis when used in combination, however, suggesting that both PDE III and PDE IV activities are important in regulating cAMP content in these cells. ${ }^{9198}$ Selective inhibitors of PDE IV may also inhibit antibody production by $B$ lymphocytes. Ro 20-1724 inhibits IgE production by peripheral blood mononuclear leucocytes and most, but not all, of this activity can be attributed to a direct inhibitory effect on the B cells. ${ }^{102}$

\section{Monocyte}

Inhibition of monocyte phosphodiesterase and the resulant rise in cellular cAMP is associated with inhibition of arachidonic acid metabolism in zymosan treated cells. ${ }^{77}$ Theophylline and other agents that increase cAMP content also inhibit the production of tumour necrosis factor in human monocytes and rat macrophages, ${ }^{103104}$ probably by a cytokine specific mechanism as phosphodiesterase inhibitors have no effect on the production of inter-leukin$1 .{ }^{103}$ Effects of isozyme-selective phosphodies- terase inhibitors on monocyte function have not been reported.

\section{Platelet}

Consistent with its phosphodiesterase isozyme profile, platelet function is profoundly inhibited by selective PDE III inhibitors. Submicromolar concentrations of several selective PDE III inhibitors, including anegralide, SKF 94120, Ro 15-2041, and siguazodan, are effective inhibitors of agonist induced calcium mobilisation, aggregation, and secretion. ${ }^{60} 89105106$ Inhibition of PDE IV or V with rolipram and zaprinast respectively has little or no effect on platelet responses. ${ }^{89}$

\section{Clinical experience

THERAPEUTIC EFFECTS

Clinical experience with the use of isozyme selective phosphodiesterase inhibitors for the treatment of asthma is limited. To our knowledge, the first such compound to be examined was zaprinast, an inhibitor of the cGMP specific phosphodiesterase (PDE V). In an initial placebo controlled, double blind crossover trial oral zaprinast $(10 \mathrm{mg})$ reduced exercise induced bronchoconstriction in adult asthmatic patients significantly, ${ }^{107}$ whereas it failed to inhibit bronchoconstriction induced by histamine. The reason that zaprinast was active against exercise induced bronchoconstriction but not histamine induced bronchoconstriction is not obvious. On the basis of the proposed role of cGMP in airway smooth muscle, we might speculate that the efficacy of zaprinast stemmed from bronchodilator activity. This explanation does not appear to be viable, however, in view of the failure of zaprinast to abrogate histamine induced bronchoconstriction. On the other hand, zaprinast might have altered neural reflexes or mediator release, perhaps through a mechanism unrelated to PDE inhibition. But it had no effect on exercise induced bronchoconstriction in a subsequent study with asthmatic children. ${ }^{108}$ Thus the positive results obtained in the earlier study were not repeated in a different group of asthmatic patients.

At least a dozen PDE III inhibitors have been evaluated for inotropic or antithrombotic activity in man but bronchodilator activity has been assessed only for one, enoximone. ${ }^{109}$ Pulmonary mechanics were studied before and after an intravenous infusion of enoximone ( 3 $\mathrm{mg} / \mathrm{kg}$ ) in 19 patients with decompensated chronic obstructive pulmonary disease. Enoximone reduced pulmonary resistance and increased dynamic lung compliance in both spontaneously breathing and artificially ventilated patients. Although long term studies have not been conducted in patients with asthma, these preliminary results suggest that enoximone can reverse bronchoconstriction in man.

Preliminary results on the activity of tibenalast, ${ }^{110}$ a PDE IV inhibitor, and benzafentrine, ${ }^{111}$ a mixed PDE III/IV inhibitor, also have been reported. The results with tibenalast were equivocal. A single oral $150 \mathrm{mg}$ dose of tibenalast caused a slight but non-significant 
increase in $\mathrm{FEV}_{1}$ in 40 asthmatic subjects. Because of the putative anti-inflammatory activity of PDE IV inhibitors, it would be of interest to assess the effect of tibenalast over a longer time. Inhalation of benzafentrine (2-32 $\mathrm{mg}$ ) by non-asthmatic subjects reversed methacholine induced bronchoconstriction, as monitored by changes in specific airways conductance, in a dose dependent manner. ${ }^{111} \mathrm{~A}$ preliminary report indicates that intravenously administered benzafentrine (40 and $80 \mathrm{mg}$ ) produced a modest and transient bronchodilatation, whereas the compound was ineffective when administered by the oral route $(9-90 \mathrm{mg}){ }^{112}$

\section{SIDE EFFECTS}

With the possible exception of the PDE III inhibitors, clinical experience with isozymeselective phosphodiesterase inhibitors is not yet extensive enough to draw conclusions about the side effect profile of the different classes of compounds. The potential for certain side effects can be predicted based on the anticipated activity of different isozyme selective inhibitors on various organs. ${ }^{97}$ For example, by virtue of their cardiotonic activity, PDE III inhibitors would be expected to produce an increase in myocardial contractility and modest vasodilation. ${ }^{28-30}$ Whether such effects would be detrimental in subjects with asthma who were otherwise healthy is unknown. Perhaps of more concern is the arrhythmogenic potential of these compounds. ${ }^{113}$ If such activity is the result of PDE III inhibition per se, it could represent a major limitation to the use of these agents to treat asthma.

The most obvious concern regarding the PDE IV inhibitors stems from their apparent antidepressant activity. ${ }^{114-116}$ The anti-depressant activity of rolipram and, presumably, other compounds of its class appears to be linked to inhibition of PDE IV in the brain. ${ }^{117}$ Whether PDE IV inhibitors will produce unacceptable central nervous system effects in individuals who do not suffer from affective disorders remains to be answered. Gastrointestinal disturbances, such as pyrosis, nausea, and vomiting, are frequently reported side effects associated with the use of rolipram..$^{11-116}$ Rolipram has also been reported to produce a rapid and pronounced fall in plasma osmolality, probably as a result of an antidiuretic effect; this resolves after seven days' treatment. ${ }^{118}$ It is not clear whether these effects are due to PDE IV inhibition in general or whether they are unique to rolipram.

Cyclic GMP is purported to have a critical physiological role in mediating vasodilation and PDE V appears to be important in regulating cGMP content in vascular smooth muscle. ${ }^{471190}$ Thus PDE V inhibitors may have cardiovascular activity.

Because of the dearth of information concerning the clinical activity of isozyme-selective phosphodiesterase inhibitors, most of the side effects discussed above are speculative. Individual agents are also likely to produce side effects that are not related to phosphodiesterase inhibition and cannot therefore be predicted.

\section{Conclusions}

Understanding of the potential role of isozyme selective phosphodiesterase inhibitors in the treatment of asthma is far from complete. Preliminary data are beginning to provide an overall sense of the potential value of these compounds. Most evidence so far suggests that PDE III inhibitors, and perhaps PDE IV and $\mathrm{V}$ inhibitors, possess bronchodilator activity. In addition, inhibitors of PDE IV may have activity against the inflammatory aspects of asthma. Little is known about the potential utility of inhibitors of PDE I and PDE II.

Attempts to broaden the therapeutic activity of isozyme selective phosphodiesterase inhibitors have been made by synthesising hybrid compounds and at least two mixed PDE III/IV inhibitors, zardaverine and benzafentrine, have undergone preliminary clinical studies. These compounds may provide an optimal combination of bronchodilator and anti-inflammatory activities. Hypothetically, a combination of PDE IV and PDE V inhibitors would have a similar therapeutic profile. Although the concept of hybrid phosphodiesterase inhibitors is superficially attractive, any loss in isozyme selectivity is likely to lead to more side effects, thus subverting one of the major proposed advantages of isozyme selective phosphodiesterase inhibitors over nonselective compounds.

After having been moribund for many years, interest in phosphodiesterase inhibitors as agents for asthma has undergone a striking resurgence, particularly with respect to the potential therapeutic advantages of isozyme selective phosphodiesterase inhibitors. An understanding of the range of activity of these compounds should emerge over the next decade as results from clinical trials become available.

We gratefully acknowledge the help of Dr Carol Kulp for conducting literature searches and Ms Dotti Lavan for her careful preparation of this manuscript.

1 Jenne JW. Physiology and pharmacodynamics of the xanthines. In: Jenne JW, Murphy S, eds. Drug therapy for asthma: research and clinical practice. (Lung biology in health and disease series.) New York: Dekker, 1987: 297-334.

2 Persson CGA. Overview of effects of theophylline. J Allergy Clin Immunol 1986;78:780-7.

3 Persson CGA, Erjefalt I, Gustafason B. Xanthinessymptomatic or prophylactic in asthma? Agents Actions 1988;23(Suppl):S137-55.

4 Weinberger M. Treatment of chronic asthma with theophylline. ISI Atlas Sci Pharm 1988;2:53-61.

5 Kuehl FA, Zanetti ME, Soderman DD, Miller DK, Ham EA. Cyclic AMP-dependent regulation of lipid mediators in white cells. A unifying concept for explaining the efficacy of theophylline in asthma. Am Rev Respir Dis 1987;136:210-3.

6 Fredholm BB. Are methylxanthine effects due to antagonism of endogenous adenosine? Trends Pharmacol Sci 1980;1:129-33.

7 Poisner AM. Direct stimulant effect of aminophylline on catecholamine release from the adrenal medulla. Biochem Pharmacol 1973;22:469-76.

8 Fink G, Mittelman M, Shokat B, Spitzer SA. TheoFink G, Mittelman M, Shokat B, Spitzer SA. Theo-
phylline-induced alterations in cellular immunity in asthmatic patients. Clin Allergy 1987;17:313-6.

9 Torphy TJ. Action of mediators on airway smooth muscle: functional antagonism as a mechanism for bronchodilator drugs. Agents Actions 1988;23(suppl):S37-53.

10 Torphy TJ, Hay DWP. Biochemical regulation of airway smooth muscle tone: an overview. In: Townley RG, Agrawal DK, eds. Airway smooth muscle: modulation of receptors and response. Boca Raton: CRC Press, 1990: receptors 
11 Bourne HR, Lichtenstein LM, Melmon KL, Henney CS, Weinstein Y, Shearer GM. Modulation of inflammation and immunity by cyclic AMP. Science 1974;184:19-28.

12 Plaut M, Marone G, Thomas LL, Lichtenstein LM. Cyclic nucleotides in immune responses and allergy. Adv Cyclic Nucleotide Res 1980;12:161-72

13 Church MK, Featherstone RL, Cushley MJ, Mann JS, Holgate ST. Relationships between adenosine, cyclic nucleotides, and xanthines in asthma. J Allergy Clin Immunol 1986;78:670-5.

14 Beavo JA. Multiple isozymes of cyclic nucleotide phosphodiesterase. Adv Second Messenger Phosphoprotein Res 1988;22:1-38.

15 Beavo JA, Reifsnyder DH. Primary sequence of cyclic nucleotide phosphodiesterase isozymes and the design of selective inhibitors. Trends Pharmac Sci 1990;11:150-5.

16 Colicelli J, Birchmeier C, Michaeli T, O’Neill K, Riggs M, Wigler $M$. Isolation and characterization of a mammalian gene encoding a high-affinity cAMP phosphodiesterase. Proc Natl Acad Sci USA 1989;86:3599-603.

17 Henkel-Tigges J, Davis RL. Rat homologs of the Drosophila dunce gene code for cyclic AMP phosphodiesterase sensitive to rolipram and RO 20-1724. Mol Pharmacol 1990;37:7-10.

18 Pittler SF, Baehr W, Wasmuth JJ, McConnell DF, Champagne MS, van Tuinen P, Ledbetter D, Davis RL. Molecular characterization of human and bovine rod photoreceptor cGMP phosphodiesterase $x$-subunit and chromosomal localization of the human gene. Genomics 1990;6:272-83.

19 Swinnen JV, Joseph DR, Conti M. Molecular cloning of rat homologues of the Drosophila melanogaster dunce cAMP phosphodiesterase: evidence for a family of genes. Proc Natl Acad Sci USA 1989;86:5325-9.

20 Livi GP, Kmetz P, McHale MM, et al. Cloning and expression of cDNA for a human low- $K_{m}$, rolipramsensitive cyclic AMP phosphodiesterase. Molec Cell Biol 1990;10:2678-86.

21 Weishaar RE, Cain MH, Bristol JA. A new generation of phosphodiesterase inhibitors: multiple molecular forms of phosphodiesterase and the potential for drug selectivity. J Med Chem 1985;28:537-45.

22 Beavo JA, Hardman JG, Sutherland EW. Hydrolysis of cyclic guanosine and adenosine $3^{\prime}, 5^{\prime}$-monophosphates by rat and bovine tissues. J Biol Chem 1970;245:5649-55.

23 Appleman MM, Avaro MA, Takemato DJ, Whitson RH. Cyclic nucleotide phosphodiesterases. In: Nathanson JA, Kebalian JW, eds. Handbook of experimental pharmacology. Vol 58/2. Berlin: Springer, 1982:262-300.

24 Thompson WJ, Appleman MM. Characterization of cyclic nucleotide phosphodiesterases of rat tissues. J Biol Chem 1971;246:3145-50.

25 Wells JN, Hardman JG. Cyclic nucleotide phosphodiesterases. Adv Cyclic Nucleotide Res 1977;8:119-43.

26 Hidaka $\mathrm{H}$, Tanaka T, Itoh $\mathrm{H}$. Selective inhibitors of cyclic nucleotide phosphodiesterases. Trends Pharmacol Sci 1984;5:237-9.

27 Weiss B. Differential activation and inhibition of multiple forms of cyclic nucleotide phosphodiesterase. Adv Cyclic Nucleotide Res 1975;5:195-211.

28 Colucci WS, Wright RF, Braunwald E. New positive inotropic agents in the treatment of congestive heart failure: mechanisms of action and recent clinical developments. N Engl J Med 1986;314:349-58.

29 Hood WB. Controlled and uncontrolled studies of phosphodiesterase III inhibitors in contemporary cardiovascular medicine. Am J Cardiol 1989;63:46-53A.

30 Wood MA, Hess ML. Review: long-term oral therapy of congestive heart failure with phosphodiesterase inhibitors. Am J Med Sci 1989;297:105-13.

31 Nielson CP, Crowley JJ, Cusack BJ, Vestal RE. Therapeutic concentrations of theophylline and enprofylline potentiate catecholamine effects and inhibit leukocyte activation. J Allergy Clin Immunol 1986;78: $660-7$.

32 Torphy TJ, Livi GP, Bacarek JM, White JR. Chilton FH, Undem BJ. Therapeutic potential of isozyme-selective phosphodiesterase inhibitors in the treatment of asthma. Second Messenger Phosphoprotein Research (in press).

33 Bergstrand $H$. Phosphodiesterase inhibition and theophylline. Eur J Respir Dis 1980;10(suppl):37-44.

34 Polson JB, Krzanowski JJ, Goldman AL, Szentivanyi A Inhibition of human pulmonary phosphodiesterase activity by therapeutic levels of theophylline. Clin Exp Pharmacol Physiol 1978;8:535-9.

35 Nielson CP, Crowley JJ, Morgan ME, Vestal RE. Polymorphonuclear leukocyte inhibition by therapeutic concentrations of theophylline is mediated by cyclic- $3^{\prime}, 5^{\prime}$ adenosine monophosphate. Am Rev Respir Dis 1988;137 25-30.

36 Bitling B, Dahlqvist R, Garli M, Hörnbland Y, Ripe E. Separate and combined use of terbutaline and theophylline in asthmatics. Effects related to plasma levels. Eur J Respir Dis 1982;63:399-409.

37 Handslip PDJ, Dart AM, Davies BH. Intravenous salbutamol and aminophylline in asthma: a search for synergy. Thorax 1981;36:741-4

38 Svedmyr K, Svedmyr N. Does theophylline potentiate inhaled $\beta_{2}$ agonists? Allergy 1982;37:101-10

39 Svedmyr N, Svedmyr K. In vitro and in vivo effects of theophylline and $\beta$-adrenostimulants in combination. Eur J Respir Dis 1980;109(suppl):83-91.
40 Barnes PJ. Endogenous catecholamines and asthma. $J$ Allergy Clin Immunol 1986;77:791-5.

41 Godard P, Chaintreuil J, Damon M, et al. Functional assessment of alveolar macrophages: comparison of cells from asthmatics and normal subjects. J Allergy Clin Immunol 1982;70:88-93.

42 Keikauf GD, Ueki IF, Nadel JA, Widdicombe JH. Bradykinin stimulates chloride secretion and prostaglandin $\mathrm{E}_{2}$ release by canine tracheal epithelium. Am J Physiol. 1985; 248:F48-55.

43 Johnson AP. Human pulmonary endothelial cells in culture: activities of cells from arteries and cells from veins. $J$ Clin Invest 1980;65:841-50.

44 Laitinen LA, Laitinen A. Innervations of airway smooth muscle. Am Rev Respir Dis 1987;136:S38-42.

45 Palmer JBA, Barnes PJ. Neuropeptides and airway smooth muscle function. Am Rev Respir Dis 1987;136:S50-4.

46 Schulman ES, Adkinson NF, Jr, Newball HH. Cyclooxygenase metabolites in human lung anaphylaxis: airway vs. parenchyma. J Appl Physiol 1982;53:589-95.

47 Lincoln TM. Cyclic GMP and mechanisms of vasodilation. Pharmac Ther 1989;41:479-502.

48 Murray KJ. Cyclic AMP and mechanisms of vasodilators. Pharmac Ther 1990;47:329-45.

$49 \mathrm{Krall}$ JF. Receptor-mediated regulation of tension in smooth muscle cells. In: Jenne JW, Murphy S, eds. Drug therapy for asthma: research and clinical practice. New York: Dekker, 1987:97-128.

50 Polson JB, Krzanowski JJ, Szentivanyi A. Inhibition of a high affinity cyclic AMP phosphodiesterase and relaxation of canine tracheal smooth muscle. Biochem Pharmacol 1983;31:3403-6.

51 Silver PJ, Hammel LT, Perrone MH, Bentley RG, Bushover CR, Evans DB. Differential pharmacologic sensitivity of cyclic nucleotide phosphodiesterase isozymes isolated from cardiac muscle, arterial and airway smooth muscle. Eur J Pharmacol 1988;1 150:85-94.

52 Torphy TJ, Cieslinski LB. Characterization and selective inhibition of cyclic nucleotide phosphodiesterase isozymes in canine tracheal smooth muscle. Molec Pharmacol 1990;37:206-14.

53 Elliott KRF, Berry JL, Bate AJ, Foster RW, Small RC. The isoenzyme selectivity of AH 21-132 as an inhibitor of cyclic nucleotide phosphodiesterase activity. J Enzyme Inhibition 1990;4:245-51.

54 Nicholson $C D$, Shahid $M$, van Amsterdam RGM, Zaagsma J. Cyclic nucleotide phosphodiesterase (PDE) isoenzymes in bovine tracheal smooth muscle, their inhibition and the ability of isoenzyme inhibitors to relax precontracted preparations. Eur J Pharmacol 1990;183: 1097-8.

55 Bergstrand $\mathrm{H}$, Lundquist B. Partial purification and characterization of cyclic nucleotide phosphodiesterase from human bronchial tissue. Molec Cell Biochem 1978;121: 9-15.

56 Cieslinski LB, Reeves ML, Torphy TJ. Cyclic nucleotide phosphodiesterase (PDEs) in canine and human tracheal smooth muscle (TSM) [abstract]. FASEB J 1988;2: A 1065 .

57 Polson JB, Krzanowski JJ, Szentivanyi A. Correlation between inhibition of a cyclic GMP phosphodiesterase and relaxation of canine tracheal smooth muscle. Biochem Pharmacol 1985;34:1875-9.

58 Murray KJ, England PJ, Hallam TJ, et al. The effects of siguazadon, a selective phosphodiesterase inhibitor, on human platelet function. Br J Pharmacol 1990;99:612-6.

59 Torphy TJ, Burman M, Huang LBF, Tucker SS. Inhibition of the low $\mathrm{K}_{\mathrm{m}}$ cyclic AMP phosphodiesterase in intact trachealis by SK\&F 94836: mechanical and biochemical responses. J Pharmacol Exp Ther 1988;246:843-50.

60 Torphy TJ, Zhou H-L, Burman M, Huang LBF. Role of cyclic nucleotide phosphodiesterase isozymes in intact canine trachealis. Molec Pharmacol 1991;39:376-84.

61 Bryson SE, Rodger IW. Effects of phosphodiesterase inhibitors on normal and chemically-skinned isolated airway smooth muscle. $B r J$ Pharmacol 1987;92:673-81.

62 Rossing TH, Drazen JM. Effects of milrinone on contractile responses of guinea pig trachea, lung parenchyma and pulmonary artery. J Pharmacol Exp Ther 1986;238:874-9.

63 Harris AL, Connell MJ, Ferguson EW, et al. Role of low $\mathrm{K}_{\mathrm{m}}$ cyclic AMP phosphodiesterase inhibition in tracheal relaxation and bronchodilation in the guinea pig. $J$ Pharmacol Exp Ther 1989;251:199-206.

64 Schneider HH, Schmiechan R, Brezinski M, Seidler J. Stereospecific binding of the antidepressant rolipram to brain protein structures. Eur J Pharmacol 1986:127: 105-15.

65 Murray KJ, Eden RJ, England PJ, et al. Potential use of selective phosphodiesterase inhibitors in the treatment of asthma. Agents Actions (in press).

66 Small RC, Berry JL, Boyle JP, et al. Biochemical and electrical aspects of the tracheal relaxant action of $\mathrm{AH} 21$ 132. Eur J Pharmacol 1991;192:417-26.

67 Gristwood RW, Sampford KA. Inhibition of histamineinduced bronchoconstriction by SK\&F 94836, salbutamol and theophylline [abstract]. BrJ Pharmacol 1987;92: and $631 \mathrm{P}$.

68 Osborn RR, Ferracone JD, Novak LB, Hand JM. Effects of rolipram $(R O)$ enantiomers on in vitro and in vivo guinea pig pulmonary models [abstract]. FASEB J 1990;4:A615 69 Bewley JS, Chapman ID. AH 21-132, a novel relaxant of 
airway smooth muscle [abstract]. Br J Pharmacol 1988; 93:52P.

70 Beume R, Eltze M, Kilian U. Bronchodilation due to inhibition of cAMP-PDE III: preclinical results on the pyridazinone derivative B 842-90. Arch Pharmacol 1987; 335(suppl):R76.

71 Ho PPK, Esterman M, Wang L, et al. LY 186655, 5,6diethoxybenzo(B)thiophene-2-carboxylic acid, sodium salt, a new orally active bronchodilator [abstract]. Pharmacologist 1987;29:173.

72 Hall IP, Walker D, Hill SJ, Tattersfield AE. Effect of isozyme selective phosphodiesterase inhibitors on bovine tracheal smooth muscle tone. Eur J Pharmacol 1990;183:1096-7.

73 Hall IP, Donaldson J, Hill SJ. Modulation of carbacholinduced inositol phosphate formation in bovine tracheal smooth muscle by cyclic AMP phosphodiesterase inhibitors. Biochem Pharmacol 1990;39:1357-63.

74 Lichtenstein LM, Margolis S. Histamine release in vitro: inhibition by catecholamines and methylxanthines. Science 1968;161:902-3.

75 Schild $\mathrm{H}$. Histamine release and anaphylactic shock in isolated lungs of guinea-pigs. $Q J$ Exp Physiol 1936; 26:165-79.

76 Dent G, Rabe K, Giembycz MA, Barnes PJ. Inhibition of eosinophil respiratory burst activity by type IV-, but no type III-selective cAMP phosphodiesterase inhibitor [abstract]. Am Rev Respir Dis 1990;141:A878.

77 Godfrey RW, Manzi RM, Gennaro DE, Hoffstein ST Phospholipid and arachidonic acid metabolism in zymosan-stimulated human monocytes: modulation by cAMP. J Cell Physiol 1987;131:384-92.

78 Takenawa $T$, Ishitoya J, Nagai Y. Inhibitory effect of prostaglandin $E_{2}$, forskolin, and dibutyryl cAMP on arachidonic acid release and inositol phospholipid metabolism in guinea pig neutrophils. J Biol Chem 1986; 261:1092-8.

79 Zurier RB, Weissmann G, Hoffstein S, Kammerman S, Tai HH. Mechanisms of lysosomal enzyme release from human leukocytes. II. Effects of cAMP and cGMP autonomic agonists and agents which effect microtubule function. J Clin Invest 1974;53:297-309.

80 Foreman JC, Hallett MB, Mongar JL. The relationship between histamine secretion and 45 -calcium uptake by mast cells. J Physiol (London) 1977;271:193-214.

81 Nielson C. $\beta$-Adrenergic modulation of the polymorphonuclear leukocyte respiratory burst is dependent upon the mechanism of cell activation. J Immunol 1987;139:2392-7.

82 Rasmussen H, Good DBP. Relationships between calcium and cyclic nucleotides in cell activation. Physiol Rev 1977;57:421-509.

83 Undem BJ, Graziano FM, Buckner CK. Effects of isoproterenol on histamine release induced from monodispersed guinea pig lung cells by different secretàgogues. $J$ Pharmacol Exp Ther 1985;233:61 7-22.

84 Undem BJ, Torphy TJ, Goldman D, Chilton FH. Inhibition by adenosine $3^{\prime}: 5^{\prime}$-monophosphate of eicosanoid and platelet-activating factor biosynthesis in the mouse PT -18 mast cell. J Biol Chem 1987;265:6750-8.

85 White JR, Ishizaka T, Ishizaka K, Sha'afi RK. Direct demonstration of increased intracellular concentration of free calcium as measured by quin-2 in stimulated rat peritoneal mast cell. Proc Natl Acad Sci USA 1984, 81:3978-82.

86 Undem BJ, Peachell PT, Lichtenstein LM. Isoproterenolinduced inhibition of immunoglobulin E-mediated releas of histamine and arachidonic acid metabolites from the human lung mast cell. J Pharmacol Exp Ther 1988;247: 209-17.

87 Kaliner M, Orange RP, Austen KF. Immunological release of histamine and slow reacting substance of anaphylaxis from human lung. IV. Enhancement by cholinergic and alpha adrenergic stimulation. J Exp Med 1972;136: 556-67.

88 Peachell PT, Undem BJ, Schleimer RP, Lichtenstein LM, Torphy TJ. Action of isozyme-selective phosphodiesTorphy TJ. Action of isozyme-selective phosphodiesFASEB J 1990;4:A639.

89 Simpson AWM, Reeves ML, Rink TJ. Effects of SK\&F 94120 , an inhibitor of cyclic nucelotide phosphodiesterase type III, on human platelets. Biochem Pharmacol 1988;37:2315-20.

90 Neilson CP, Vestal RE, Sturm RJ, Heaslip R. Effects of selective phosphodiesterase inhibitors on the polymorphonuclear leukocyte respiratory burst. J Allery Clin Immunol 1990;86:801-8.

91 Thompson WJ, Ross CP, Pledger WJ, Strada SJ, Banner RL, Hersh EM. Cyclic adenosine 3':5'-monophosphate phosphodiesterase. Distinct forms in human lymphocytes and monocytes. J Biol Chem 197f 251:4922-9.

92 Robicsek SA, Krzanowski JJ, Szentivanyl A, Polson JB. High pressure liquid chromatography of cyclic nucleotide phosphodiesterase from purified human T-lymphocytes. Biochem Biophys Res Commun 1989;163:554-60.

93 White JR, Torphy TJ, Christensen SB IV, Lee JA, Mong S. Partial purification of the rolipram sensitive phosphodiesterase from human monocytes [abstract]. FASEB $J$ 1990;4:A1987.

94 Macphee $\mathrm{CH}$, Harrison SA, Beavo JA. Immunological identification of the major platelet low- $K_{m}$ CAMP phosphodiesterase: probable target for antithrombic agents. Proc Natl Acad Sci, USA 1986;83:6660-3.

95 Frossard N, Landry Y, Pauli G, Ruckstuhl M. Effects of cyclic AMP- and cuyclic GMP-phosphodiesterase inhibitors on immunological release of histamine and on lung contraction. Br J Pharmac 1981;73:933-8.

96 Busse WW, Anderson VL. The granulocyte response to the phosphodiesterase inhibitor Ro 20-1724 in asthma. J Allergy Clin Immunol 1981;67:70-4.

97 Nicholson CD, Challiss RAJ, Shahid M. Differential modulation of tissue function and therapeutic potential of selective inhibitors of cyclic nucleotide phosphodiesterase isoenzymes. Trends Pharmacol Sci 1991;12:19-27.

98 Robicsek SA, Blanchard DK, Djeu J, Krzanowski JJ, Szentivanyl A, Polson JB. Attenuation of human T-lymphocyte blastogenesis by the selective inhibition of cAMP-phosphodiesterase [abstract]. FASEB J 1990;4: A337.

99 Chilton FH, Schmidt D, Torphy T, Goldman D, Undem B. cAMP inhibits platelet activating factor (PAF) biosynthesis in human neutrophil [abstract]. FASEB J 1989; 3:A308.

100 Plaut M, Marone G, Gillespie E. The role of cyclic AMP in modulating cytotoxic T lymphocytes. II. Sequential changes during culture in responsiveness of cytotoxic lymphocytes to cyclic AMP-active agents. J Immunol 1983;131:2945-52.

101 Averill LE, Kammer GM. Inhibition of interleukin 2 production is mediated by a cyclic adenosine monophosphate (cAMP)-dependent pathway [abstract]. Clin Res 1985;33:839A

102 Cooper KD, Kang K, Chan SC, Hanifin JM. Phosphodiesterase inhibition by Ro 20-1724 reduces hyper-IgE synthesis by atopic dermatitis cells in vitro. $J$ Invest Dermatol 1985;84:477-82.

103 Lee JC, Votta B, Dalton BJ, Griswold DE, Bender PE, Hanna N. Inhibition of human monocyte IL-1 production by SK\&F 86002. Int J Immunother 1990;6:1-12.

104 Renz H, Gong J-H, Schmidt A, Nain A, Gemsa D. Release of tumor necrosis factor- $x$ from macrophages. Enhancement and suppression are dose-dependently regulated by prostaglandin $\mathrm{E}_{2}$ and cyclic nucleotides. J Immunol 1988 ; 141:2388-93.

105 Muggli R, Tschopp TB, Mittelholzer E, Baumgartner HR 7-Bromo-1,5-dihydro-3,6-dimethylimidazo(2,1-b)quinazolin-2(3H)-one (Ro 15-2041), a potent antithrombotic agent that selectively inhibits platelet cyclic AMP-phosphodiesterase. J Pharmacol Exp Ther 1985;235:212-9.

106 Seiler S Arnold AJ, Grove RI, Fifer CA, Kelly SL, Stanton HC. Effects of anagrelide on platelet cAMP levels, cAMPdependent protein kinase and thrombin-induced $\mathrm{Ca}^{++}$ fluxes. J Pharmacol Exp 1987;243:767-74.

107 Rudd RM, Gellert AR, Studdy PR, Geddes DM . Inhibition of exercise-induced asthma by an orally absorbed mast cell stabiliser (M\&B 22,948). Br J Dis Chest 1983; 77:78-86.

108 Reiser J, Yeang Y, Warner JO. The effect of zaprinast (M\&B 22,948 , an orally absorbed mast cell stabilizer) on exerciseinduced asthma in children. $\mathrm{Br} J \mathrm{Dis}$ Chest 1986;80 157-63.

109 Leeman M, Lejeune P, Meot C, Naeije R. Reduction in pulmonary hypertension and in airway resistance by enoximone (MDL 17,043) in decompensated COPD. Chest 1987;91:662-6.

110 Israel E, Mathur PN, Tashkin D, Drazen JM. LY 186655 prevents bronchospasm in asthma of moderate severity [abstract]. Chest 1988;94:71S.

111 Foster RW, Rakshi K. Bronchodilator potency, effectiveness and time course of inhaled nebulised AH 21-132 in normal human subjects [abstract]. Br J Pharmacol 1990; 99:193P.

112 Small RC, Foster RW, Berry JL, Chapman ID, Elliott KRF. The bronchodilator action of AH 21-132. Agents Actions (in press)

113 Naccarelli GV, Goldstein RA. Electrophysiology of phosphodiesterase inhibitors. Am J Cardiol 1989;63:35-40A

114 Horowski R, Sastre-Y-Hernandez M. Clinical effects of the neurotropic selective cAMP phosphodiesterase inhibitor rolipram in depressed patients: global evaluation of the preliminary reports. Curr Ther Res 1985;38:23-9.

115 Bobon D, Breulet M, Gerard-Bandenhove MA, et al. Is phosphodiesterase inhibition a new mechanism of antidepressant action? A double blind double-dumm study between rolipram and desipramine in hospitalized major and/or endogenous depressives. Eur Arch Psychiatr Neurol Sci 1988;238:2-6.

116 Eckmann F, Fichte K, Meya U, Sastre-Y-Hernandez M. Rolipram in major depression: results of a double-blind comparative study with amitriptyline. Curr Ther Res 1988;43:291-5.

117 Wachtel H. Potential antidepressant activity of rolipram and other selective cyclic adenosine $3^{\prime}, 5^{\prime}$-monophosphate phosphodiesterase inhibitors. Neuropharmacology 1983, 22:267-72.

118 Sturgess I, Searle GF. The acute effect of the phosphodiesterase inhibitor rolipram on plasma osmolality. $\mathrm{J}$ Clin Pharmacol 1990;29:369-70.

119 Lugnier C, Schoeffter P, LeBec A, Strouthou E, Stoclet JC Selective inhibition of cyclic nucleotide phosphodiesterases of human, bovine and rat aorta. Biochem Pharmacol 1986;35:1743-51.

120 Souness JE, Brazdil R, Diocee BK, Jordan R. Role of selective cyclic GMP phosphodiesterase inhibition in the myorelaxant actions of M\&B 22,948, MY -5445, vinpocetine and 1-methyl-3-isobutyl-8-(methylamino) xanthine. Br J Pharmacol 1989;98:725-35. 